\title{
THE ROYAL COMMISSION ON THE POOR LAWS, 1905-09
}

Although there is some truth in the comment made by Canon Barnett, rector of St Jude's, Whitechapel, and founder of Toynbee Hall, that the issue in 1909 of the Report of the Royal Commission on the Poor Laws "may mark the beginning of a new epoch in our social life", 1 the precise reasons for the appointment of the Commission on December 4th, 1905, are not yet known. The Conservative government, which made the appointment almost on the eve of its defeat, had been in power for ten years, first under the prime ministership of Lord Salisbury and then, until his resignation in December 1905, of A. J. Balfour. During that time the cost of the Poor Law had risen steadily, and yet, until the end of 1904, either through social myopia or a preoccupation with the greater drama of events abroad, the government displayed little interest in the problem of the Poor Law or, indeed, in any of the wider questions of social reform.

Beatrice Webb, that determined Fabian, writing in her diary at Torquay on January 31,1900 , summed up the mood of impatience and despair which existed among social reformers during the early days of the Boer War. "The last six months [...] have been darkened by the nightmare of war", she wrote. "The horrible consciousness that we have, as a nation, shown ourselves to be unscrupulous in methods, vulgar in manners as well as inefficient, is an unpleasant background to one's personal life". To her and her husband, public affairs seemed "gloomy"; the middle classes were "materialistic" and the working class "stupid, and in large sections sottish". The government of the country was firmly in the hands of "little cliques of landlords and great capitalists", while the rich were "rolling in wealth" and every class, except the sweated worker, had "more than its accustomed livelihood". "The social enthusiasm that inspired the intellectual proletariat of ten years

1 New Poor Law or No Poor Law. Being a Description of the Majority and Minority Reports of the Poor Law Commission. With an introductory note by Canon Barnett (London, 1909), p. ix. 
ago has died down", she mourned, "and given place to a wave of scepticism about the desirability, or possibility, of any substantial change in society as we know it."' Charles F. G. Masterman, Liberal author, journalist and politician, agreed with her. Seeking to estimate what he called the "realities at home", he, too, deplored the waning enthusiasm for social reform during the previous twenty years. "Programmes of social reform repose on the dusty shelves of the brains of great statesmen", he complained. "The "Condition of the People' problem, once so insistent, ceases [...] to trouble the public mind. It appears local, parochial, a problem of gas, water and drains; politicians feel ashamed to allude to it in public." This reluctance to acknowledge the problem he attributed to several causes: the apparent prosperity, a lack of leaders, the weariness of the poor, and, above all, imperialism. "It is the day of other and noisier enthusiasms", he sadly decided, "the lust of domination, the stir of battle, the pride in magnitude of empire, delight in rule over alien nations, commercial aggrandisement, and dissatisfaction with anything short of predominance in the councils of the world."'2

Yet despite this public devotion to the "noisier enthusiasms", it was impossible to close one's eyes to the fact that the "Condition of the People" problem was assuming a more menacing form. Although unemployment was not so serious as it was later to become, it was serious enough, in the autumn of 1903 , to induce a group of experienced charity organizers to institute a Mansion House Fund to aid the unemployed in four boroughs in London's East End. This achieved little, but it drew attention to the fact that, as Walter Long, President of the Local Government Board, later told the Royal Commission, "the unemployed difficulty" had grown so acute in towns such as London, Liverpool, Manchester, Birmingham and Leeds, that crowds demanding assistance were "besieging the offices of the Relieving Officers and Guardians" and, in some places, finding that poor relief brought "deprivation of all civil rights", had "turned their attention to the Municipalities and demanded that great works should be carried out $[\ldots]$ on which they should be employed". ${ }^{3}$ Faced with this situation, the Balfour government began to devise the Unemployed Workmen Bill, and, at the same time, in December 1904, to consider

1 Beatrice Webb, Our Partnership, ed. by Barbara Drake and Margaret I. Cole (London, 1948), pp. 194, 195.

2 The Heart of the Empire. Discussion of Problems of Modern City Life in England (London, 1901), p. 4.

${ }^{3}$ Royal Commission on the Poor Laws and Relief of Distress. Separate Report by the Rev. Prebendary H. Russell Wakefield. Mr. Francis Chandler, Mr. George Lansbury and Mrs. Sidney Webb (hereafter called Minority Report), p. 545, quoting Evidence before the Commission, q. 78466. 
the appointment of a Royal Commission as a long-term attempt to grapple with the problems the bill was designed to meet immediately. ${ }^{1}$

When the Unemployed Workmen Bill became law, it embodied the policy of Joseph Chamberlain's Circular of 1886 that "respectable workmen", temporarily unemployed, should be given work by the municipal authority of the district in which they lived. This was official recognition of that class of people whose condition and environment were, as the Commissioners later reported, "a discredit and a peril to the whole community". ${ }^{2}$ Moreover, since the Act could be interpreted as a kind of guarantee that the government would help working men who were unemployed during a depression, it indicated yet once again how far relief authorities had abandoned in practice the Poor Law principles of 1834 , especially the twin principles that the able-bodied pauper should receive relief only in a workhouse and that his condition should be made "less eligible" than that of the independent labourer. It also reinforced a conviction, especially strong in the Poor Law Division of the Local Government Board, that this practice of developing services outside the Poor Law should be checked and a return made to the strict principles of 1834 . In fact, so intent on achieving this objective was James Stewart Davy, head of the Poor Law Division, that he seized upon the appointment of the Royal Commission as a means to this end, organized a campaign to "railroad" the Commissioners into reaching his pre-determined conclusion, after which, in a moment of blazing indiscretion, he revealed his machinations to the one Commissioner, Beatrice Webb, least likely to fall in with his plan. ${ }^{3}$ This was both frantic boast and foolish word,

1 John Brown has quoted a letter, dated December 6, 1904, from Walter Long, then President of the Local Government Board, to the Prime Minister, in which Long urges the justification "for a fresh Inquiry". See "The Appointment of the Poor Law Commission", in: Bulletin of the Institute of Historical Research, XIII (1969), pp. 239-42. See also K. D. Brown, "Appointment of the Poor Law Commission. A Rejoinder", ibid., XLIV (1971), pp. 315-18, in which the appointment is described as "simply a tactical manoeuvre, rather than the result of any long considered conservative strategy", and John Brown's reply, "Poor Law Commission and the 1905 Unemployed Workmen Act", ibid., pp. 318-23.

2 Report of the Royal Commission on the Poor Laws and Relief of Distress [Cd 4499] (London, 1909) (hereafter called Majority Report), Vol. II, Pt IX, $\S 173$. All references are to this edition unless stated otherwise.

${ }^{3}$ Our Partnership, p. 322. Beatrice Webb's diary from 1905 to 1909 , printed in ch. VII of Our Partnership, is, of course, the most comprehensive and the most fascinating account of the inner life of a Royal Commission that we have, but, being unashamedly partisan, it should be handled with care. For other versions of the Commission, see Una Cormack, The Welfare State (Loch Memorial Lecture, 1953, printed by Family Welfare Association), and Raymond Postgate, The Life of George Lansbury (London, 1951). 
for Mrs Webb and her husband led a rival school of thought, who were equally convinced that the principles of 1834 had been proved obsolete and that a public enquiry into the working of the Poor Law was to be welcomed, since inevitably it would reveal, not only the large amount of poverty which still existed in England, but also the immense progress of collective social provision through the new health, education and other services which had been developing since 1834. In 1905, the forces standing behind these two schools of thought were ready for battle. When, too, the President of the Local Government Board was Gerald Balfour, the Prime Minister's brother - "a philosopher", as Beatrice Webb explained, "who recognised the public advantage of a precise discrimination between opposing principles"' 1 - and the Prime Minister himself seemed responsive to new ideas, the stage was set for the public inquisition into the past, present and possible future of that unique institution, the English Poor Law.

The Royal Commission appointed on December 4th, 1905, was charged, not only with the investigation of the working of the Poor Law, but also (and this was a significant recognition of the antiquated nature of the existing system) with an investigation into the various means adopted outside the Poor Law "for meeting distress arising from want of employment" and a consideration of "whether any, and if so, what, modification of the Poor Laws or changes in their administration or fresh legislation for dealing with distress are advisable".2 These terms of reference were so wide that they caused concern in some quarters. For example, the Charity Organisation Society, which was to play a leading part in the proceedings, had hoped for "a proper limitation of the scope of the inquiry" in order to protect the Commissioners against the "advocacy of persons who $[\ldots]$ are in favour of a complete reconstruction of our social and industrial economy". Policy in the past, said the Society's spokesman, had been too much influenced by "the insistence of the socialist argument", and he hoped that the government would not "put the principal rival controversialists on the Commission and allow them to wrangle their way through to half a dozen minority reports". "The subject of the inquiry is really a very simple one", said he. "We want to have a system which will secure humane and adequate relief for those for whom this is

1 Our Partnership, p. 317. Beatrice Webb ascribed the creation of the Commission "to the coincidence of there being, as newly appointed head of the poor law division [...] (James Stewart Davy) intent on reaction; and, as President of the Local Government Board [...] (Mr. Gerald Balfour) [...]. There was, in fact, in official circles, an uneasy feeling that there had been, during the last two decades, an unwilling drift away from the principles of 1834 , and one which sooner or later had to be decisively stopped." Ibid.

2 Majority Report, Vol. I, Pt I, p. 15. 
absolutely necessary, but at the same time [...] to interfere as little as possible with the self-dependence of the individual citizen which this provision obviously endangers." 1

This point of view was to receive a good airing on the Commission, for of the twenty members appointed, six were prominent members of the COS and included Octavia Hill, one of the Society's founders, C. S. Loch, its general secretary, and Helen Dendy Bosanquet, its historian. In addition, there were five Guardians of the Poor, including Labour representatives such as George Lansbury and Francis Chandler, the permanent heads of the Local Government Boards of England, Scotland and Ireland, two political economists, one from the University of Glasgow and the other from Oxford, representatives of the Church of England and the Roman Catholic Church in Ireland, Charles Booth, ship-owner, merchant and inventor of the social survey (although he was forced to retire from the Commission in 1908 because of ill health), and, of course, that indefatigable Socialist and Poor Law investigator, Beatrice Webb. A Conservative ex-Cabinet Minister, Lord George Hamilton - "this experienced politician and attractive grand seigneur", as Beatrice Webb described him ${ }^{2}$ - was appointed Chairman. The Commission was, in fact, a body of experts, either in Poor Law administration or in social investigation. Many of them, such as C. S. Loch and Beatrice Webb, were already distinguished as creative social thinkers and practical reformers; others, such as George Lansbury and Francis Chandler, represented those new political pressures at work in the electorate which demanded reform; all were acknowledged to be men and women sincerely interested in the welfare of the poor and freer than most from the dictates of private ambition. "There is one very pleasant feature about the Commission", Beatrice Webb recorded in her diary. "We are all of us after public objects, however much we may disagree as to what these objects are and how to arrive at them. There is hardly any personal vanity, or personal ambition, and no personal interest at work in the Commission." 3

Very soon, however, the work of the Commission resolved itself into a conflict between two opposing groups, with the Poor Law Division of the Local Government Board, supported by the COS, ranged against the Fabian-Labour quartet led by Beatrice Webb, working, as always, in close harmony with "The Other One", who was actually to

1 Article, unsigned but obviously written by C. S. Loch, on "The Royal Commission", in: Charity Organisation Review, New Series, XVIII (1905), pp. 141, 142-43.

2 Our Partnership, p. 321.

3 Ibid., pp. 331-32. 
write the Minority Report. ${ }^{1}$ No doubt the high-handed tactics of Mrs Webb, combined with her sense of superiority, her love of manipulation, and unco-operative behaviour, which made her, as she herself admitted, "somewhat of a handful", 2 made the differences seem more irreconcilable than they were. And perhaps, too, this failure to reach agreement, as one critic has argued, destroyed the possibility of building a comprehensive, well-articulated system of social services. ${ }^{3}$ Nevertheless the differences between the Majority and the Minority Reports when they were presented early in 1909 , were not so profound as their makers believed, and the two Reports - hailed on their issue as "undoubtedly [...] the most important Blue Book of our time"4 were to mark the end of 1834 and the beginning of a new period in the history of social welfare in England.

\section{II}

Before we examine the differences between the two Reports, however, it is worth looking at some of the evidence which the Commissioners presented on the working of the Poor Law, for not only does this give us a picture of informed opinion on the major problems of the day, but it also throws a blaze of light on the lives of those thousands of people who, for one reason or another, had lost the battle of existence and who, with their dependants, now formed the host with whom the Poor Law dealt. By 1908 their numbers were considerable. On any given day, the Commissioners pointed out, even omitting the casuals and insane, there were nearly 800,000 paupers in England - half of them women, the other half men and children -, and this number was equal to the population of Liverpool. Taking a yearly count, the number was even higher. For the twelve months from September 30, 1906, there were no less than $1,709,436$ people under the care of the Guardians -47.7 per 1,000 people - which was almost equal to the population of Liverpool, Manchester and Birmingham combined. ${ }^{\mathbf{5}}$ These men,

1 Margaret Cole, Beatrice Webb (London, 1945), p. 99. There was fierce criticism of this fact when the Webbs claimed the copyright of the Minority Report, which, of course, they could not have done if other signatories had contributed even a line. E.g., "Never before [...] has the Report of a Royal Commission [been] written in great part by one who has neither been appointed to the Commission, nor has been present at its meetings nor heard the evidence." The Minority Report. A Criticism (London, 1910), p. 5. A summary of this appeared in The Times, June 9, 1910.

2 Our Partnership, p. 358.

${ }^{3}$ Una Cormack, The Welfare State, op. cit., pp. 21, 32-33.

4 The Report of the Poor Law Commission. Reprinted from the Times (London, 1909), Preface, p. 3.

${ }^{6}$ Majority Report, Vol. I, Pt II, § 4-7. 
women and children were granted relief in accordance with the principles of 1834, as amended by practice and by the various orders of the central authority. Except in cases of physical infirmity, relief was given in the workhouse, the classes of paupers and the sexes being segregrated, and their conditions of life made "less eligible" than those of able-bodied paupers outside the workhouse.

For a long time little was known about these people, for although many of the inspectors did their work well, there had been no major report on the Poor Law since 1834 . Then it had been found that there were more than 14,000 children under sixteen in the general mixed workhouse, that the large lunatic and feeble-minded population moved freely among the other inmates, including children and pregnant women, and that the infant, the sick and the aged were looked after by their fellow paupers. It was found, too, that the sick formed onethird of the Poor Law's clientele, and that outdoor relief was not, as often supposed, given indiscriminately, but primarily to the sick, the aged and the infirm. This group, eking out an existence on outdoor relief, was even more of an enigma than the inmates of the workhouse, for prior to the Commission of 1905-09 no one had ever enquired into how they lived, why they were destitute, what use they made of their relief money, or to what extent they required medical attention. Now in 1909, for the first time, the two Reports of the Commission, based on evidence collected by skilled investigators from every corner of the country, presented a wonderfully vivid and moving portrait of what was happening to the people on relief inside and outside the workhouse.

The picture was not an edifying one. Certainly some of the workhouses in the country might be "picturesque old buildings with pleasant gardens" and "ten to twenty acres of ground attached" on which the inmates could be set to work growing vegetables, ${ }^{1}$ but other workhouses, especially in London, where the system had been developed to its fullest extent, were not so fortunate. Here the committees of investigation found institutions which were over-crowded, dirty, badly managed, inadequately staffed, and often with no attempt made to classify the inmates. "There is little or nothing to be said in praise of this house", one investigator reported. "The sanitary arrangements were disgraceful, the laundry was in a state of chaos, and the accommodation in the tramp wards was primitive. [...] The inmates were sitting round fires in small rooms with low ceilings, and seemed morose and indifferent to their surroundings." "Most of the people looked even more dejected than usual", reported another, "hardly one seemed to have enough spirit to speak when spoken to."2

1 Ibid., Pt IV, § 185.

2 Ibid., $\S 190$. 
No wonder, then, that there existed in all parts of the country and among all classes the greatest dislike and distrust of the workhouse. The respectable poor had a horror of it and would not go into the house at all unless compelled. "The Workhouse and everything within its walls is anathema excepting to the very dregs of the population", announced the Medical Investigator, Dr McVail. It is "the supreme dread of the poor". "Life in the Workhouse does not build character up", said another. "It breaks down what little independence or alertness of mind is left. [...] It is too good for the bad and too bad for the good." 1

In this universally condemned workhouse, some categories of paupers suffered more than others. Babies and infants, for whom no provision had been made in the 1834 Report, were probably the worst off. They were taken into the workhouse with their parents and often separated from their mothers. More than one-third of them died each year. ${ }^{2}$ Sometimes, since the Guardians required the mothers to go out to work, the children were locked up in a deserted room all day; at other times they were left with careless neighbours, or in the cha1ge of nursing mothers, the aged or the infirm. Sometimes a whole nursery was left in charge of a person certified as of unsound mind. One feebleminded woman was set to wash a baby; she did so in boiling water, and the child died. ${ }^{3}$ In one workhouse nursery, a committee found babies, one or two years old, preparing for their afternoon sleep. They were seated in rows on wooden benches in front of a wooden table on which was a long narrow cushion. When the babies were "sufficiently exhausted, they fell forward upon this to sleep". This system, the committee was told, was an invention of the matron, and had been in use for a long time. ${ }^{4}$ Epidemics of measles and whooping cough were common in the nurseries, for no arrangements were made to quarantine the sufferers.

When they were three or four years old, the children went to a workhouse school, or were boarded out, for a small sum, to foster parents living within the same Union or to certified schools and homes managed by voluntary philanthropic committees. Sometimes, too, after the Sheffield Guardians had shown the way, the children went to "Scattered Homes", which had distinct advantages over other

\footnotetext{
1 Minority Report, p. 15, quoting Evidence before the Commission, q. 71398, Report $[\ldots]$ on the Methods and Results of [...] Poor Law Medical Relief, by Dr John C. McVail, 1907, p. 146, and Memorandum on Certain Aspects of Poor Law Administration, by A. D. Steel-Maitland and R. E. Squire, p. 1.

${ }^{2}$ Minority Report, p. 83.

${ }^{3}$ Ibid., p. 88, quoting the Report of the Royal Commission on the Care and Control of the Feeble-minded, 1908, Vol. VI, p. 221; Vol. VIII, p. 22.

4 Ibid., p. 91, quoting Reports of Visits by Commissioners, No 24, p. 65.
} 
systems in that the foster parent was more carefully selected, regular medical inspection was provided; there was continuous skilled supervision of the home, and the children were less "institutionalized" and could mix with other children at school and play. But even after 1870, when school attendance of five-year-olds became compulsory, the Poor Law authorities still maintained their own workhouse schools, where as many as two thousand pauper children would be herded together, where they were expected to spend part of each day in domestic service, and where they forever alternated between classroom and kitchen because no provision was made for holidays and, in any case, there was nowhere they might go.

Confronted with these conditions, the more aristocratic members of the Royal Commission might still pay tribute to the esprit de corps to be found in Poor Law Schools and applaud the "abundant evidence" that those educated in these schools "carry away with them a memory of happy days spent the1e, $[\ldots]$ a real sense of gratitude to the officers, and $[\ldots]$ a bond of union of no mean strength". ${ }^{1}$ This, perhaps, may have been true for the fortunate few strong enough or insensitive enough to withstand the oppressiveness of their early surroundings, but to our modern ears, there is greater conviction in the words of the Children's Investigator, who deplored "the retention of children" in workhouses because "even where they had special attendants", they were never completely separated from the inmates or the atmosphere of the house. "In York certainly", he concluded, "the children were dull and inert; they stood about like moulting crows, and did not seem to be able to employ themselves with any enthusiasm or vigour."2

The aged and the infirm fared a little better than the children, chiefly because, as "impotents", they were regarded as a class apart and not likely to abuse the relief granted them. If they were considered "deserving" at the time of application, had shown signs of thrift in the past, had no relatives or charitable sources to support them, and could be properly taken care of, they were granted outdoor relief, although this was often so niggardly as to provide only the barest food, clothing and shelter with none of the comforts, indulgences or amenities of life. Sometimes this "irresponsible penuriousness" of the Destitution Authority, as the Minority Report noted, "may in the neighbourliness of rural life $[\ldots]$ be supplemented by casual gifts", but since the majority of the destitute aged lived in "large towns of mean streets and migratory populations", these supplements could not be relied upon. Worse still, outdoor relief was often refused "merely on the

1 Majority Report, Vol. I, Pt IV, § 438.

Minority Report, p. 112, quoting Report [...] on the Condition of the Children, by Dr W. Williams, 1908, p. 103. 
grounds that the applicants have no resources whatever", so that even the most deserving of the aged were often forced to enter the general mixed workhouse. "Rather than give a lonely old woman as much as seven shillings a week, they refuse to give anything", the Minority Report angrily exclaimed. "The worst of the tragedy is that it is especially the shrinking, silent semi-starvation of the lonely old women, or disabled old men, $[\ldots]$ who have outlived relations and friends, which is least likely to be helped." The result was that "with a feeling that it is just like death", the old person was forced to enter the workhouse to join "the Aged Poor of Bad Conduct". 1

Towards the end of the century, however, there was a change of spirit. A Royal Commission on the Aged Poor in 1895, although it rejected various schemes for state assistance to the aged, did recommend ways of improving the condition of the "aged deserving poor" in the workhouse. Likewise Charles Booth and others pressed for old-age pensions, which, after several committees had considered the subject, were granted by an Act of 1908; cottage homes were mooted for the aged, while in the administration of outdoor relief, the Guardians gave the impression, as one witness said, that they desired "to be more easy with the people". So much so, it was noted disapprovingly, that in rural districts, in all parts of the country, outdoor relief "is practically regarded as an old-age pension [...] given to all comers of a certain age". ${ }^{2}$

If the aged and the infirm in the workhouse were a catalyst of change, so, too, were the sick, around whom a cluster of medical services had grown up, which, in 1909, was to earn the warm commendation of the Royal Commissioners. The grant of outdoor medical relief and the institution of sick wards within the workhouses to treat ordinary cases of illness and pregnancy were, after the 1860's, supplemented by isolation hospitals for infectious cases, infirmaries for the non-infectious, and a growing number of dispensaries, many of them free, to cater for the sick not actually in need of institutional care. These, originally intended for treatment of paupers only, were now attracting well-to-do patients who would not have gone into them in the old days. "It has become the custom, in certain residential quarters of the Metropolis, for the servants of wealthy households freely to use the Poor Law Infirmary", the Commissioners were told. "In the more industrial quarters, the skilled artisans and the smaller shop-keepers are coming to regard the Poor Law Infirmary $[\ldots]$ much as they do the public park or library - as a municipal institution, paid for by

1 Ibid., pp. 256, 257, 279.

2 Majority Report, Vol. I, Pt IV, § 331-33. 
their rates, and maintained for their convenience and welfare."1

But there was a darker side to this picture to which the Commissioners drew attention. There were only two medical inspectors to inspect some thousand Poor Law institutions in England and Wales: a senior inspector, whose work was chiefly confined to London, and a junior inspector for the provinces. Medical officers were underpaid, and, as they were required to provide from their own salaries any medicines required by the sick paupers in their charge, they were sometimes unwilling or unable to provide the best treatment possible. Sick wards, especially in rural areas, were often badly built, overcrowded, inadequately lit and ventilated, and lacking a sufficient water supply. Many patients died through want of proper nursing. A more efficient classification of the sick was needed and separate institutions set apart for people suffering from phthisis, consumption and other infectious or sub-infectious diseases. There was also a lack of uniformity between districts in the treatment of the sick poor, so that a destitute person who happened to be ill in one Union might be less well cared for than his confrère who fell ill in another. In fact, said the Minority Report, the very principle of the Poor Law Medical Service - its restriction to persons who proved themselves to be destitute - involved delay and reluctance in the application of the sick person for treatment, hesitation and delay in beginning the treatment, and, in strictly administered districts, actual refusal of all treatment to people who were in need of it, but who could manage to pay "for some cheap substitute". ${ }^{2}$ What was needed, the Minority Report continued, was not a division according to the presence or absence of destitution, but a division according to the services to be provided, and, with brilliant insight, went on to advocate a scheme similar to the universal, tax-supported medical service which Britain enjoys today. ${ }^{3}$

This, however, was in the future. In 1909, despite the improvements which had taken place in the system of medical assistance to the poor, the lot of the pauper in search of medical relief was not an easy one,

1 Minority Report, pp. 197-98.

2 Ibid., p. 231.

${ }^{3}$ E.g., "The experience of the past [...] demonstrates $[\ldots]$ beyond possibility of doubt that when a Destitution Authority departs from the simple function of providing bare maintenance under deterrent conditions, it finds it quite impossible to mark off or delimit its services from those which are required by, and provided for, the population at large." (Minority Report, pp. 394-95) And again, "A Health Service having for its first and great aim the prevention of disease, embracing the present Public Health, Medical Charities and Poor Law Hospital Services [...] would, I consider, particularly if managed as a State Service, be a forward step of immense benefit to the public health and poor of the country." (Ibid., pp. 229-30) 
and had he heard the claim made by some of the Commissioners that "the sick poor were probably never so well looked after as they are at the present day", it probably would have evoked from him a wry smile. This would have been particularly so in the case of the 60,000 mentally ill, for whom no special provision was made in the workhouse. Although the Lunacy Act of 1862 had authorized the creation of suitably equipped wards within the workhouse for their care, no local authority had availed itself of the Act, nor was the Poor Law Board insistent that separate provision should be made for them. Thus although a Royal Commission on Mental Deficiency in 1904 had recommended that all mental defectives should be removed from the Poor Law and dealt with by special authorities, the Poor Law Commissioners, five years later, could still describe the "terrible sights" they had seen:

"We have seen feeble-minded boys growing up in the Workhouse year after year untaught and untrained, alternately neglected and tormented by other inmates, because it had not occurred to the Board of Guardians to send them to (and to pay for them at) a suitable institution. We have ourselves seen - what one of the Local Government Board Inspectors describes as of common occurrence - 'idiots who are physically offensive or mischievous, or so noisy as to create a disturbance by day and by night with their howls', living in the ordinary wards, to the perpetual annoyance and disgust of the other inmates. We have seen imbeciles annoying the sane, and the sane tormenting the imbeciles. We have seen half-witted women nursing the sick, feeble-minded women in charge of the babies, and imbecile old men put to look after the boys out of school hours. We have seen expectant mothers, who have come in for their confinements, by day and by night working, eating and sleeping in close companionship with idiots and imbeciles of revolting habits and hideous appearance."2

Such was the plight of many of the poor in England in 1909.

Meanwhile what of the able-bodied pauper? The series of depressions in agriculture, industry and commerce from the 1880's onwards and the increasing incidence of unemployment made the provision of some kind of relief a matter of necessity. "Offering the house" to the ablebodied was not considered desirable because the effects of a sojourn in the workhouse, all agreed, were wholly bad. Even men "above the ordinary working class" appeared to "lose their manhood", reported one workhouse chaplain. The able-bodied "easily become enervated

1 Majority Report, Vol. I, Pt V, § 118.

${ }^{2}$ Minority Report, pp. 238-39. 
and lose all desire to rise again to true citizenship and individual responsibility." It was pitiable to see "the mental torture which decent people suffer when circumstances compel them to enter the workhouse - there comes a loss of self-respect and a moral deterioration." 1 It had also become obvious that the numbers of unemployed had reached such proportions that "the house" could not accommodate all of them, and since the second resource of the Poor Law for dealing with the able-bodied unemployed, emigration, was so little used, the unemployed had to be sent to the Labour Yard or the Test Yard attached to the workhouse, where relief could be given in return for a task of work. But this, too, had its disadvantages, for unless the Yard was closely supervised, the premises large and suited to the work done, and skilled enquiry officers were in attendance to check imposture, the men did practically what they liked, and "in frosty, very wet or snowy weather", complained one of the Guardians at Leicester, "they sit in the shed around the fire smoking and talking, and further confirming the habits of laziness which many of them had already acquired."2

Other methods in use had proved equally ineffectual in handling the growing numbers of unemployed. Municipal relief works, encouraged by Chamberlain's Circular of 1886 , had been proved "economically useless", because if "ordinary work" was undertaken, it merely forestalled and later threw out of work men more or less regularly employed by the councils, and if it was "sham work", it had an even more deleterious effect on the worker than direct relief. ${ }^{3}$ Likewise the Unemployed Workmen Act of 1905, which developed and legalized the scheme of Joint Committees devised by Walter Long, President of the Local Government Board, to deal with unemployment in London, was a failure, for as a scheme which encouraged casual labour subsidized out of public funds, it was thought to undermine the independence and efficiency of the working classes, and hence, the Majority claimed, should be repealed. ${ }^{4}$ Nor had the array of charitable organizations any greater success in handling the unemployed. In fact, "the intervention of sporadic and unorganised charity in times of special distress from want of employment", the Majority Report said sternly, "has done little good and much harm", 5 for unless charity was administered

1 Majority Report, Vol. I, Pt VI, § 327, quoting Summary of Reports of Workhouse Chaplains as to the effect of life on inmates, pp. $6(1), 21,18$.

${ }^{2}$ Minority Report, pp. 453-54, quoting Evidence before the Commission, q. 47005 .

${ }^{3}$ Majority Report, Vol. I, Pt VI, § 408, quoting Jackson and Pringle's Report on Unemployment, p. 148.

4 Ibid., $\$ 471$.

5 Ibid., § 382. 
according to certain well-defined rules, it could demoralize the recipient and prevent him from ever becoming an independent and self-reliant citizen. The Minority Report, too, deplored the "undermining of a penal Poor Law" by "extensive indiscriminate, unconditional and inadequate relief by Voluntary Agencies". This, it said, had resulted in the growth of a class of "born-tireds, who are ever ready to receive something for nothing", and concluded that the whole problem of ablebodied destitution must be systematically dealt with by the National Government. ${ }^{1}$

\section{III}

Here, then, is the picture of England's less fortunate classes which the Royal Commission on the Poor Laws presented in 1909. Three features stood out: the morass of destitution which, despite England's vaunted wealth and power, still remained at the base of her society, the proved incapacity of the traditional methods of the Poor Law and private charity to handle it, and the growth, outside the Poor Law, of a network of new health, education and other services for particular classes of people, financed out of rates and taxes and costing in the aggregate more than the whole Poor Law expenditure. These "silent up growths of the last half century", as Beatrice Webb called them,$^{2}$ had produced on the one hand a wasteful and costly duplication of services, and, on the other, had left behind them the Boards of Guardians and the Poor Law Division of the Local Government Board in a state of antiquated inefficiency. What was to be done?

In the early days of the Commission, there had been a great deal of emphasis on the necessity to return to the principles of 1834 . The official attitude to the relief of the poor had been clearly revealed in the cross-examination of James Stewart Davy, principal officer of the Poor Law Division of the Local Government Board. The destitute man, he admitted, had a right to relief, but it was not a complete right, "for the necessary sanctions are lacking". Since he could not sue for his rights, it was the duty of the State to see that he got them. Davy admitted the moral responsibility to relieve, but he maintained a rigid attitude on the principle of deterrence. The lot of the pauper, he said, was still to be "less eligible" than that of the independent labourer, and he defined less eligibility as consisting of "loss of personal reputation (what is understood by the stigma of pauperism) $[\ldots]$, the loss of personal freedom, which is secured by detention in a workhouse,

1 Minority Report, pp. 525, 528.

${ }^{2}$ Introduction to Pt I of the Minority Report, printed in Social Welfare in Transition. Selected English Documents 1834-1909, ed. by Roy Lubove (Pittsburgh, 1966), p. 202. 
and $[\ldots]$ the loss of political freedom by suffering disfranchisement". ${ }^{1}$ $\mathrm{He}$, therefore, favoured the able-bodied test workhouse, where work "both irksome and unskilled" should be the test of relief, and when asked by one of the Commissioners whether disfranchisement was not too severe for men out of work through no fault of their own, he replied firmly that the unemployed man "must stand by his accidents; he must suffer for the general good of the body politic."' 2

This attitude, however, under pressure of the facts unearthed by the Commission's investigators, was to soften considerably during the course of the Commission, so that by the end of 1909 the Majority could report that since the name Poor Law had gathered about it "associations of harshness, and still more of hopelessness", it hoped to show the way to "a system of help which will be better expressed by the title of Public Assistance than by that of Poor Law". ${ }^{3}$ Although this did not go as far as the Minority Report, which advocated the complete "break up" of the Poor Law and the subsititution of a number of specialized services to meet the needs of different categories of people, the Majority's use of phrases such as "a system of help" and "public assistance" did indicate a definite departure from the principles of 1834 to which Davy and his supporters had earlier proclaimed allegiance. For whereas the Royal Commission of 1834 had blamed the individual for his poverty, the Commission of 1909 drew attention to "modifications and developments in our industrial system which cannot be ignored". 4 Whereas in 1834 the government's policy was one of deterrence rather than prevention, in 1909 recommendations were made for such positive measures as a national system of employment exchanges, the extension of technical education, the tightening up of child labour laws, and even the institution of public works.

There was a significant change, too, in the attitude to the workhouse. Accepted without question in 1834, in 1909 it had been abandoned, by implication, as a "test" of pauperism. Here was the essential difference between 1834 and 1909. Pauperism was to be treated, not tested, and the concept of "less eligibility" was to give way to the concept of social provision against poverty. "What we are aiming at", stated the Majority Report, "is, instead of a system of allowances, granted capriciously and irresponsibly to meet a constantly increasing demand,

1 Royal Commission on the Poor Laws and Relief of Distress, Appendix, Vol. I, Minutes of Evidence, q. 2230. See also answers to qq. 2027, 2229, 2033, 2036, 2318,2366 and 2375.

2 Ibid., q. 3219.

3 Majority Report, Vol. II, Pt IX, § 3.

4 Ibid., Vol. I, Pt VI, § 304. 
to substitute a system of careful and varied assistance, in which the 'allowance' will be only one of many forms of help, and which will be directly designed to raise the recipients, or where that is not possible the children of the recipients, to a position of independence."1 Here the concept of treatment has been substituted for the concept of less eligibility, but there were certain reservations. In speaking of the general mixed workhouse, the Majority Report pointed out that it could act as a deterrent in the case of the aged and infirm to whom it might "legitimately be a refuge", but added: "At the same time we think it will be a great misfortune if the aged should be brought to prefer life in the workhouse (under whatever name it may in future be known) to an independent life amongst their own friends and relations". ${ }^{2}$ Again, in describing the work of separate infirmaries as "practically 'State' or rate-aided hospitals", the Majority Report pointed out that "where the association of medical relief with the Poor Law had been lessened or disguised" - as in the case of separate infirmaries - there had been an increase in the number of people availing themselves of the system, and that these had come from the well-to-do rather than the poorer classes. "We are not inclined, therefore", the Report said, "to make medical assistance so attractive that it may become a species of honourable and gratuitous selfindulgence instead of a somewhat unpleasant necessity resorted to because restoration of health is otherwise impossible." 3 In other words, what was wanted was not too much, but a little, deterrence.

On other matters, however, the Majority Report spoke with the same voice as the more radical minority. It condemned the general mixed workhouse and believed that the administration of the Poor Law should be transferred to the ordinary local authorities. It recommended a substantial extension of the social services, under or outside the Poor Law, for the sick, the aged, children and the mentally defective. It wanted to see a national system of labour exchanges established to deal with the unemployed, and, since "there seems room and necessity for a great extension of insurance against unemployment", especially amongst unskilled and unorganized labour, it declared that, in order to encourage trade unions and other voluntary organizations to extend their unemployed benefits, "we have not hesitated to recommend the encouragement of a State subsidy". A compulsory scheme of un-

1 Ibid., Pt IV, $\S 301$. For an interesting discussion of the attitude to the poor of Charles Booth and other Commissioners, see A. M. McBriar, "Charles Booth and the Royal Commission of the Poor Laws, 1905-1909", in: Historical Studies (University of Melbourne, Australia), XV (1973), pp. 722-36.

2 Majority Report, Vol. I, Pt IV, § 222.

3 Ibid., Pt V, § 220.

4 Ibid., Vol. II, Pt IX, § 132. 
employment insurance, however, it could not endorse, for "no scheme either foreign or British which has been brought before us", it stated, "is so free from objections as to justify us in specifically recommending it for general adoption". " Pensions for the old and incapacitated, too, were suspect, for the Majority preferred to rely on thrift and savings to prevent distress. Nevertheless they confessed themselves as "almost driven to the conclusion that a new form of insurance is required, which, for want of a better name, we may call Invalidity Insurance", but hastily added:

"Whatever be the risk insured against, whether it be sickness, accident, old age or unemployment, the possibility of such insurance depends on the existence of savings, whether these savings be in private or collective hands, or be put in the hands of the State by taxes which represent the savings, or what otherwise might be the savings of its citizens."2

Thus the two Reports had a great deal in common. Both wished to co-ordinate existing relief, to classify those in need, to supervise the aid given to them, and to avoid any system of assistance, even to the sick and the aged, based on unconditional relief. Beatrice Webb, in a letter to her sister in March 1911, summarized what she called "the philosophy of the Minority Report":

"If we could get all our effort, public and private, really organised and registered, I believe the money we are already spending in a chaotic and spasmodic way would be more than sufficient to do the job efficiently. But we must have behind all this good-will and expenditure, the element of compulsion and disciplinary supervision of the persons who are aided, and that could only be exercised by a public authority."'3

The Majority Report agreed with this philosophy, but not with the machinery by which the Webbs proposed to implement it. For the Webbs had looked at the chaos of the Poor Law in a predominantly laissez-faire society and had imagined, in detail, the pattern of administration which would replace the Poor Law in a society based upon social and economic planning. Since people became destitute from a variety of causes, they said - from old age, from ill health or

1 Ibid., § 133.

2 Ibid., Pt VIII, $\$ 10,12$.

${ }^{3}$ Beatrice Webb to Georgine Meinertzhagen, March 1911, Passfield Papers, British Library of Political and Economic Science, quoted by John Brown, "Social Judgements and Social Policy", in: Economic History Review, Second Series, XXIV (1971), p. 112. 
accident, from mental disease, from the loss of a breadwinner, from wages too low or too intermittent to support a family, or from an inability to find work - these causes should be tackled at the source by responsible administrators with expert knowledge, and the various forms of prevention and relief co-ordinated into a nation-wide scheme. Local authorities, through their health and education services, should provide the assistance needed by children, the sick, the aged and the mentally ill. Those above sixty-five should receive State pensions. The problem of those whose wages were too low should be tackled by the national fixing of a minimum wage, and that of the unemployed by a policy of public works administered nationally and locally. The Poor Law, as such, would disappear altogether, and the local authorities would appoint Registrars of Public Assistance, whose task would be to keep a register of all who were receiving public assistance in any form, and who would assist with relief grants persons who had fallen into destitution and were not being adequately catered for through any of the recognized sources. ${ }^{1}$

But this proposal to transfer Poor Law functions to the general public services was too revolutionary for its times. It was denounced as "a Socialist document"2 - which was hotly denied by Mrs Webb herself $^{3}$-, while even those less antagonistic to the scheme pointed out that, since it was based on no previous experience, it was, in W. A. Bailward's words, "a proposal for a leap absolutely in the dark". 4 This was certainly true, for when the Poor Law Commissioners began their investigations in 1905, there were no old-age pensions, no health or unemployment insurance, few homes for the aged (except for the workhouses), few general hospitals under public control (except for the infirmaries); the treatment of mental deficiency was still in its infancy; free meals for school children were a novelty; and Care Committees under the local education authorities were just beginning to appear. In other words, the Webbs' plan, as T. H.

1 See Minority Report, Summary of Conclusions and Recommendations of Pt I, and Pt II, pp. 690-716.

${ }^{2}$ The Minority Report. A Criticism, op. cit., p. 4.

3 "The Minority Scheme is not socialistic. [It] does not involve or even lead to the nationalization of the means of production, distribution and exchange. It is a sort of social main drainage system, a necessary basis to a civilised society upon whatever principle it is based." "The Prevention of Destitution", in: Royal Commission on the Poor Laws and Relief of Distress. A Course of Nine Lectures in Sheffield, 1909-1910, ed. by H. Scurfield (Sheffield Weekly News reprint), p. 17.

${ }^{4}$ The Reports of the Poor Law Commissioners of 1834 and 1909. A Paper read before the Society of the Poor Law Workers on May 10, 1909 (London, 1909), p. 7 . 
Marshall pointed out, was a brilliant anticipation of the eventual results of a movement which had just begun and of which they sensed the nature, except for their rejection of compulsory insurance. ${ }^{1}$ Thus considering the novelty of the Minority's proposals, it was no wonder that many looked askance at them and, as a result, under-estimated the degree of unity which existed between the two Reports.

\section{IV}

Despite an underlying unity, however, there were two major points of disagreement between the Majority and Minority Reports, which reflected a divergence in the philosophies of welfare on which they were based. In the first place, the Reports differed in their conception of the respective roles of the State and the voluntary agencies. The Majority Report, harking back to familiar ideas propounded by the COS and other bodies, wanted their programme of treatment to be carried out primarily by the voluntary agencies, with State action limited to dealing with cases regarded as ineligible for private charity, either because the applicants were thriftless, given to drink or leading immoral lives, or because their poverty was chronic and hence beyond the means of private charity to deal with effectively. These people were "defaulters in the contract of social obligation", as C. S. Loch called them. "They do not maintain themselves. They throw the fulfilment of their obligation on others - on the State or on members of the community", ${ }^{2}$ and because they were defaulters, they needed the supervision, control and disciplinary treatment provided by the Poor Law Guardians or their proposed successors, the Public Assistance Committees. But those applicants whose need was temporary, and who showed signs that they would respond to the bracing qualities of private charity, were to be cared for by the Voluntary Aid Committees, to be set up alongside the Public Assistance Authority to deal with "temporary need due to non-current causes", and including in their ranks "persons of experience" capable of administering to the "curative treatment" necessary to restore their clients to "independent habits of life". 3

In order to make this plan effective, the Majority Report introduced a new form of "less eligibility": public assistance to the able-bodied was to be "less agreeable" than the assistance given by the Voluntary Aid Committee. This, it considered, would not only maintain the

1 T. H. Marshall, Social Policy in the Twentieth Century (London, 1968), p. 41. 2 "Solidarity Considered as a Test of Social Condition in England", in: Charity Organisation Review, New Series, XXVI (1909), p. 263.

${ }^{3}$ Majority Report, Vol. I, Pt VI, § 616. 
distinction between the recipients of public and private assistance, but would ensure that the private donor would not be deterred from his almsgiving, for, as the Report confided, somewhat naively, unless the assistance of the Voluntary Aid Committee was "superior", the Committee might find it difficult to collect the voluntary subscriptions necessary to help "deserving cases of unemployment". 1

This proposal to establish a national system of voluntary aid to act, in Loch's words, as "the friendly assistant of a revised, and, to a great extent, a new Poor Law"2 was designed to give charitable bodies a definite and responsible place in the social administration of the country, because it was believed that, especially in Great Britain, "the home of voluntary effort", 3 the voluntary agency, despite the encroachment of the State, still had an important role to play, both in shoring up the system of social security and in rehabilitating the destitute who remained. The proposal was also in keeping with the Majority's views on the importance of the new profession of social casework, which had emerged within the framework of the COS and other charitable organizations, and which aimed to cure the moral degradation which pauperism entailed by "rescuing" the character of the degraded. How to ferret out, beneath the surface of dependence, apathy and hopelessness, some elements of character and will-power which could be utilized to bring the poor back to be self-respecting members of society - this was conceived to be the problem of the early caseworker. "In the deep souls of those who appear the worst", as Octavia Hill had said, "there is a spark of nobleness." "Charity is a social regenerator", Loch added, "she has to support new desires; to revive old instincts; to keep alive family affections; $[. .$.$] to preserve$ the humane in man. We have to use Charity to create the power of self help."5

In pursuing this aim "to preserve the humane in man", social work, by 1905, had broken free from many of its Lady Bountiful traditions. Originally based on the concept of charity, it had evolved from a set of rules to guide volunteers in their work as friendly visitors of the poor into a philosophy which embodied many of the principles of modern casework and a technique which could be transmitted by education and training from one generation of social workers to

1 Ibid., § 623.

8 "The Report of the Royal Commission on the Poor Law and the Relief of Distress", in: Charity Organisation Review, New Series, XXV (1909), p. 77. 3 Majority Report, Vol. II, Pt IX, § 169.

${ }^{4}$ Life of Octavia Hill as told in her Letters, ed. by C. Edmund (London, 1913), p. 61 .

" "The Future of Charity", in: Charity Organisation Reporter, No 551 (September 27, 1884), pp. 320, 321. 
another. Now came an invitation to casework, with its concomitants of the interview, the visit, the investigation and the case committee, to step outside the confines of the voluntary organizations and to aid the Public Assistance Committees in their treatment of pauperism. "We mean that every family applying [for public assistance] should be looked upon as unique", the Majority Report insisted. In every case there should be "a complete knowledge of the facts"; the assistance given should be adequate and carefully adapted to the needs of the individual; it should include "processes of help which would be preventive, curative and restorative", and be aimed "to foster the instincts of independence and self-maintenance amongst those assisted". ${ }^{1}$ "No case which has ever touched the Poor Law should be left to drift unaided", said Miss Harlock, one of the Commission's special investigators, stressing the benefits which could accrue if a family was wisely counselled. "I have come across cases [...] where it is likely that if a strong and wise friend could be found they might be placed upon an independent economic footing. It is so often not only financial aid that is needed but friendship and advice. It is sometimes thought that the religious and charitable agencies provide this, but in only one case have I discovered any attempt on the part of such agencies to build up the economic independence of the family."'2

This concern to treat the family as a unit was, of course, part of the ancient tradition of the Poor Law in England, and although it sometimes had pernicious results, such as the practice of treating the whole family as paupers if the head became a pauper, it also had advantages, since social work is always more effective if based upon the family unit. It is also true, as the Majority realized, that treatment of family problems can be more effectively handled by an undifferentiated agency, rather than a number of specialist organizations, and this was one of the reasons which led the Majority to denounce their rivals' scheme "to break up the Poor Law" as "faulty and unworkable":

"We consider that the many and subtle problems associated with Public Assistance, especially when it is a family rather than an individual that requires rehabilitation, cannot be solved by the simple process of sending off each unit to a separate authority [...]. What is needed is a disinterested authority, practised in looking at all sides of a question, and able to call in skilled assistance. The specialist is too apt to see only what interests him".3

1 Majority Report, Vol. I, Pt IV, § 293, and Vol. II, Pt IX, § 71.

${ }^{2}$ Ibid., Vol. I, Pt IV, $\S 297$, quoting Report of an Inquiry in Six Unions into Cases of Refusal of Outdoor Relief, Miss Harlock, p. 37.

${ }^{3}$ Ibid., Vol. II, Pt IX, § 13. 
But this proposal that the State should administer a Poor Law while a network of voluntary agencies dealt sympathetically with "deserving" cases represented the antithesis of everything the Webbs and their supporters believed in. They were convinced that full responsibility for policy and its execution should rest on the public authority, which should make use of voluntary helpers and the voluntary agencies as it thought fit. Furthermore, they could not accept the principle of discriminating between one class of people who would be in the care of the voluntary agencies and another who would be passed on to the public authority. This seemed to them a reversion to the principles of 1834 with their assumption that those provided for by the Poor Law suffered in some way from "moral defect" and should be dealt with in such a way as to deter others from applying for public treatment. Thus the Majority and Minority Reports differed in their conception of the respective roles of the State and the voluntary agencies in the treatment of pauperism.

The second point on which the two Reports disagreed was more fundamental. While both groups favoured the extension of State services for the children, the sick, the aged and the unemployed, the Majority believed that there would always be a residue of people who needed "continuous treatment", which could best be provided by a Destitution Authority, or, as it was now to be called, the Public Assistance Authority. "Frail old persons" without relatives or friends to care for them, children neglected by their parents, the feeble-minded not so ill as to be certified insane but yet unable to look after themselves, people suffering from chronic illnesses, unmarried mothers whose "career of vice" should be checked, the loafers, the "ins-andouts", the gamblers and alcoholics, for whom "there appears to be no hope of applying beneficial continuous treatment, except under conditions of discipline and deterrence"1 - these people, having in common the characteristics of poverty and helplessness, needed something more than relief in cash or in kind or the intermittent attention of specialized agencies. They needed somebody who would take charge of their lives, who, while making decisions on their behalf, would yet seek to wean them from habits of dependence, and who, as a "guardian", would treat them, not as paupers to be punished, but as "wards in poverty" to be protected. This the Destitution Authority was intended to do."

1 Ibid., $\$ 151$.

2 The illuminating phrase "wards in poverty" is taken from Marshall, Social Policy in the Twentieth Century, op. cit., p. 43, to whose interpretation of the role of the Destitution Authority I am indebted. See ibid., pp. 41-43. 
But to the Minority, a Destitution Authority, either as the sole dispenser of public assistance or as one of several authorities providing for the destitute was nothing more than the old Poor Law under a new name, and they recommended that the Poor Law Authority be superseded by, and its functions distributed among, the newer specialized local authorities already at work. Thus children of school age should be dealt with by the local Education Committee, the sick, the infirm, the infant and the aged by the Health and Pensions Committees, and the mentally defective of all grades and ages by the Asylum Committee, all to be presided over by a Registrar of Public Assistance who should co-ordinate the various activities to assess the charges to be made for particular kinds of relief and treatment. ${ }^{1}$ "What is demanded by the conditions is not a division according to the presence or absence of destitution", the Minority argued, "but a division according to the services to be provided."2

This did not mean that the Minority proposed to provide "free services". Far from it. They wanted people to pay according to their means and to feel that it was a reciprocal obligation if they accepted a service. So a great deal of emphasis was placed on the recipient's obligation to co-operate with treatment, whether for sickness or unemployment, as a means of developing the social, economic and moral qualities of effective citizenship. If this co-operation was not forthcoming, the Minority did not hesitate to resort to the bridle and the spur. The unemployed man, for instance, who could not be immediately placed by the National Labour Exchange, was to be packed off to a Training Establishment for a course in physical and moral improvement, but if he proved recalcitrant, he was to be "judicially committed to a Detention Colony". ${ }^{3}$ The Webbs, in their efforts to apply scientific principles to the management of human affairs, were adamant that all relief should be conditional. Two years later, of course, they were to fight Lloyd George's "rotten scheme of sickness insurance", as Beatrice Webb called it, because it gave an unconditional right. "Any grant from the community to the individual [...] ought to be conditional on better conduct", Mrs Webb said severely. "What the Government shirk is the extension of treatment and disciplinary supervision [...]. No attempt is made to secure an advance in conduct, in return for the increased income." What was wanted, she added grimly, was compulsory training and "no nonsense about democracy".4

1 Minority Report, pp. 395-411.

2 Ibid., p. 395.

3 Ibid., p. 673.

Our Partnership, pp. 475, 417, 468, 418. 
These, then, were the different ways in which the Majority and the Minority Reports proposed to treat the problem of destitution. Yet, despite the monumental labours of the Commissioners in drawing up their proposals, their own anticipation that these would be "of use in promoting legislative measures and administrative reforms", ${ }^{1}$ and the unparalleled sales of the two Reports in England, the Royal Commission failed to initiate any major reform in the relief of poverty prior to 1914. One reason for this was undoubtedly the split within the Commission. Had the Report been unanimous, it might have been, as Canon Barnett said, "invincible", 2 but the division of opinion over the break-up of the Poor Law seemed irreconcilable in 1909, and was further exacerbated when the Webbs, dismayed by the "magnificent reception" accorded the Majority Report, ${ }^{3}$ enlisted all the financial and intellectual resources at their disposal - the Fabian Society, the young University people, the progressives of every creed and class whom they could reach - into a giant nation-wide propaganda campaign to influence public opinion and to force the Liberal government to accept and implement their proposals. As publicity, it must have been superb, stamping the Webbs' view of Poor Law reform on the minds of their listeners and contributing to that "stir and ferment", that "atmosphere of hopeful debate", which J. B. Priestley has described as being characteristic of the Edwardian era. ${ }^{4}$ Yet as a means of persuading those in power to put the proposals into operation, it was, if anything, counter-productive, because the Webbs risked antagonizing members of both the government and the opposition. "I am not sure that your plan of knife to knife opposition is the best and that there is not here the opportunity for something of that persuasiveness of which you and Mr. Webb are masters", Haldane's sister wrote to Beatrice Webb in $1909,^{5}$ while an entry from Austen Chamberlain's diary throws and interesting light on what was going on behind the scenes:

"After his speech and Wyndlam's, A. J. B[alfour], Long, Lyttelton

1 Majority Report, Vol. I, Pt I, p. 27.

2 "On the issue of the Report, he [Barnett] was much troubled, having so earnestly hoped that the members would be unanimous and thus invincible". Canon Barnett. His Life. Work and Friends, by his Wife (London, 1919), II, pp. 284-87.

${ }^{3}$ See Beatrice Webb's entry in her diary for February 18, 1909, Our Partnership, p. 425.

4 J. B. Priestley, The Edwardians (London, 1970), pp. 121, 92, 119.

5 E. S. Haldane to B. Webb, 1909, Passfield Papers, quoted by Michael E. Rose, The Relief of Poverty, 1834-1914 (London, 1972), p. 47. 
and myself retired to Balfour's room to consider our attitude to a private members' bill which embodies the policy of the Minority Report of the Poor Law Committee. Balfour, who had not read it or given much consideration of it but who had seen the Webbs, was the most favourably inclined to it. The rest of us, who had gone a little deeper into it, were agreed that it would not do, though I confessed to having been greatly attracted to it before I studied it."

Chamberlain then went on to state his objections to the scheme: it was too costly, it established an intolerant bureaucratic tyranny, and it made "the position of the State-aided better than that of the ordinary decent working man taxed to support them". ${ }^{1}$

But perhaps more serious than this alienation of potential allies was the effect the Minority campaign had of throwing the signatories and supporters of the Majority Report into the arms of the status quo party, thereby greatly strengthening the ranks of those who opposed any changes in the system. In the process, most of the progressive reforms which the Majority had advocated slipped from view. By 1910, when a Prevention of Destitution Bill incorporating the proposals of the Minority Report had been drafted by Henry Slesser, then a young lawyer and an active member of the Fabian Society, and had received its second reading in the House, it had become clear that the issue lay not between the Majority and Minority proposals, but between both and the status quo.

Forefront in the ranks of those fighting to maintain the status quo were the firmly entrenched and immensely powerful Boards of Guardians, who had refused to accept the sentence of death imposed on them by the two Reports and vented their spleen at the annual Poor Law Conferences. "Some of the recommendations [of the Commission] trespass considerably upon the cherished preserves of officials", Mr F. H. Bentham, who had served on the Commission, told the Guardians soothingly at their Conference in 1909. "This need not cause much uneasiness, as good officials are indispensable, come what may in alterations of machinery or of law."2 But the Guardians refused to be mollified. "The Commissioners have failed to make out a case against the present Poor Law authorities", stated Henry J. Marton, $\mathrm{JP}$ and ex-Chairman of the Birmingham Board of Guardians. "We

${ }^{1}$ Quoted in Our Partnership, p. 450.

2 "The Report of the Royal Commission on the Poor Laws with regard to Administration", in: Proceedings of the Central and District Poor Law Conferences held from May 1908 to April 1909, with the Papers read and discussion thereon, and Report of the Central Committee (London, 1909), p. 663.

3 Ibid., p. 712. 
are threatened with destruction", fumed another, "why should we be abolished? What have we done or left undone to deserve such a fate? [...] there is abundant proof of the excellence and suitability of the present system. [...] I think we still have a long lease of life before us." "It is not likely that Boards will quietly submit to the proposals for their abolition", the Secretary to the Association of Poor Law Unions pointed out, "it is not probable that Parliament [...] will easily be persuaded to bring about their destruction", ${ }^{2}$ while in the other corner of the ring, the Reverend L. R. Phelps, MA, Fellow of Oriel College, Vice-Chairman of the Oxford Board of Guardians and himself a Royal Commissioner, was goaded into justifying his claim that there was "something akin to rottenness in our Poor Law Denmark". "We have had a Poor Law at work for over seventy years", he stated bluntly. "We have had a system of education side by side with it for thirty five years. We have had a great and most encouraging growth in the sense of civic duty, in knowledge, in devotion to the cure of social ills. And with all this, the problem of pauperism is where it was! A solid mass of three-quarters of a million paupers, a growth in male pauperism, a rise in cost, a halt in progress."3

But neither the voice of the Rev. Mr Phelps and his fellow Commissioners nor the increasingly strident voice of the Webbs could convince the officials of the Poor Law Division of the Local Government Board and their political chief, John Burns, of the necessity for change, whether by prescription of the Majority Report or that of the Minority. The Liberal government set its face resolutely against legislative reform of the Poor Law, and Burns stubbornly maintained that he could effect by administrative measures any reform considered necessary. Meanwhile Lloyd George, the most powerful force in the government, was working on an entirely different method of dealing with the question of destitution, and, apparently oblivious of the recommendations of the Royal Commission, was drawing up his own programme of social insurance. Although this scheme for sickness and later unemployment insurance left untouched both the evils and the cost of the Poor Law, it "gave the go-by to all the proposals of the Royal Commission", as the Webbs sorrowfully noted, ${ }^{4}$ and the plans

1 Thomas Palmer, "The Abolition of the Guardians", in: Proceedings of the Central and District Poor Law Conferences held from May 1909 to February 1910, pp. 561, 562, 573.

2 Herbert Davy, "The Report of the Royal Commission on the Poor Laws", ibid., p. 148.

3 Report of the Proceedings of the Twenty-Seventh Annual Poor Law Conference for the South Midland District, held at Town Hall, Oxford, May 21, 1909, pp. 83, 82 .

4 S. and B. Webb, English Poor Law History, Pt II (London, 1929), p. 723. 
over which the Commissioners had laboured for four years, to extinguish the Boards of Guardians and to transfer their powers to the County and Municipal Authorities and to the National Government, were quietly shelved. This reprieve for the Guardians was to last for twenty years, until one morning in March 1930, twelve months after the Local Government Act had been passed, The Times printed an announcement. "At midnight tonight", it said, "a page of English local history will be turned over. The Guardians of the Poor will cease to hold office and their functions will be transferred to the County Borough Councils and the County Councils."'

\section{VI}

Yet, although the Royal Commission had no noticeable effect on the activities of Parliament during the crucial years from 1906 to 1912, its effects were by no means negligible. If England's Welfare State is, as we have come to think, a State which used its powers to guarantee individuals and their families a minimum income, to protect them against social contingencies such as sickness, old age and unemployment, and to make available to all citizens an agreed range of social services, then the sum of the disunited efforts of the Royal Commission was, to use Una Cormack's phrase, "the Welfare State in embryo".2 Between them, the Majority and the Minority Reports, with their different emphases, acknowledge these responsibilities. Although it is nowhere specifically mentioned, the underlying principle of the Minority Report, and to a lesser extent the Majority Report, is clearly that of a "National Minimum".

This was a slogan which the Fabians had used from the mid-nineties to support their advocacy of extensions of the factory acts, their campaigns against sweating, their demands for arbitration and the eight-hours day, and for old-age pensions, improved housing, and the extension of educational facilities. It was gradually becoming recognized, they claimed, that the State had a duty to preserve certain standards below which no citizen should be allowed to fall. ${ }^{3}$ This was the principle which the Minority Report embodied in its proposals. To Beatrice Webb, the sole purpose of the Report, as she said later, was "to secure a national minimum of civilised life $[. .$.$] open to all$ alike, of both sexes and all classes, by which we meant sufficient nourishment and training when young, a living wage when able-

1 The Times, March 31, 1930.

2 Una Cormack, The Welfare State, p. 32.

${ }^{3}$ For a history of the concept, see A. M. McBriar, Fabian Socialism and English Politics 1884-1918 (Cambridge, 1966), especially pp. 107-08, 257-60, and on the Royal Commission on the Poor Laws, pp. 266-74. 
bodied, treatment when sick, and a modest but secure livelihood when disabled or aged". 1 That this National Minimum was not to be interpreted solely in materialist terms, as many of her detractors claimed, was made equally clear. To her, prevention of mass destitution, in all its forms and no matter what its causes, was not only a way of ensuring that each person would have the necessaries of life; it was also a way of replacing misery by happiness. "In making these recommendations", she asked herself, looking back from the standpoint of 1911, "were we right or were we wrong in assuming that they would or could $[\ldots]$ ensure to the workers by hand and by brain steady progress in health and happiness, honesty and kindliness, culture and scientific knowledge, and the spirit of adventure?"'2

The incorporation of this ideal of the National Minimum into British welfare policy, however, had to wait until the 1940's, for even before the Royal Commission presented its Reports, the stage had been set for a different kind of attack on the problem of poverty. The Liberal government, rejecting the proposals to reform or abolish the Poor Law proposed by the Royal Commission, had discovered a third option, whereby it retained the Poor Law substantially unchanged, but sought to reduce pauperism by attacking its causes piecemeal. This was the programme of the "New Liberalism", and it was to engage the attention of England's statesmen and reformers until the beginning of the First World War.

1 Our Partnership, pp. 481-82.

2 Ibid., p. 477. 